\title{
Problems of Translating English Idiomatic Expressions into Arabic
}

\section{Lubna M. Khoshaba}

English Department, College of Education and Languages, Lebanese French University, Erbil, Kurdistan Region, Iraq.

lubna.markus@lfu.edu.krd

\section{ARTICLE INFO}

\section{Article History:}

Received: $1 / 8 / 2021$

Accepted: 13/9/2021

Published: Autumn 2021

Keywords: Idioms,

Opaque, Transparent,

Literal translation,

Adaptation.

Doi:

10.25212/Ifu.qzj.6.4.37

\begin{abstract}
Idioms have been defined as groups of words or phrases used together to have fixed meanings. No doubt, ideas or thoughts have been expressed differently in different languages. Using the idiomatic expressions is one of the ways that can be used to convey the intended meaning indirectly. Many researches have been carried out in this respect to show the importance of idioms and how problematic it is the process of translating them from one language into another knowing that this phenomenon is culture-specific. This research paper aims at translating idiomatic expressions from English into Arabic. The current study ends with the following conclusions: (1) idioms are culture specific, (2) Idioms are of two kinds. They are a: transparent and b: opaque, and (3) most idiomatic expressions were translated communicatively and in certain cases adaptation was used. These two types of translations result in effective renderings.
\end{abstract}

\section{Introduction}

Idioms are defined as phrases or expressions that have fixed structures. The meaning that can be conveyed by using the idiomatic expressions is either literal or figurative. Historically, the word idiom is derived from the French word "idiome" which means private property. Hockett (1970: 303 ) states that idioms are constantly created in any living language, some of them are used for a long time, others might be forgotten. He also mentions that formation of new idioms is important even if it is small, simply, because it will have an essential effect on the field of linguistics. Idioms are associated with historical, geographical and cultural factors. So, people from different cultures may not understand some expressions like the idiomatic ones. This case results in 


\section{QALAAI ZANISTSCIENTIFIC JOURNAL \\ A Scientific Quarterly Refereed Journal Issued by Lebanese French University - Erbil, Kurdistan, Iraq \\ Vol. (6), No (4), Autumn 2021 \\ ISSN 2518-6566 (Online) - ISSN 2518-6558 (Print)}

problems in translation. Another factor related to the idiomatic expressions which is the social class. For example, nowadays, the new generation are interested in the new technology, so they use some words that might be unfamiliar for those who are not interested in. from what have been said so far, people create idioms depending on their usage socially.

People speak idiomatically even if they do not know that. It can be said that idioms are used in everyday language and in literature as well. Structurally, idioms are group of words combined together with a specific meaning. Using the words of these idioms will result into different meanings. The participants tend to use the idiomatic expressions to make something clear when other words do not express it clearly.

Regarding Chomsky's theory (1975:57) of generating sentences with formal and semantic properties, the meaning of a sentence is determined by the rules of syntax and semantics as well as the intention of the participant which makes the sentence understandable.

\section{Classification of Idioms}

Elewa (2015: 220) classifies idioms into five types according to their variation in terms of transparency of meaning. These types are as follows:

1. Transparent and literal idioms, for example, put the blame on.

2. Semi-transparent idioms, such as, pull strings.

3. Semi-opaque idioms, as in this example, break the ice.

4. Opaque idioms, like, kick the bucket.

5. Misleading idioms, for example, war chest.

The participants tend to use the idiomatic expressions to make something clear when other words do not express it clearly.

\section{Idioms in Terms of Transparency and Opaqueness}

Semantically speaking, Ulman (1962:45) distinguishes between transparent and opaque words and believes that the transparent words have meaning which can be understood from the meaning of their parts, while the meaning of the opaque words can be determined in the same way as the transparent ones. As it is mentioned earlier that the idiomatic expressions have fixed meaning and structure, therefore; they can 


\section{QALAAI ZANISTSCIENTIFIC JOURNAL \\ A Scientific Quarterly Refereed Journal Issued by Lebanese French University - Erbil, Kurdistan, Iraq \\ Vol. (6), No (4), Autumn 2021 \\ ISSN 2518-6566 (Online) - ISSN 2518-6558 (Print)}

be considered as opaque expressions since their meaning cannot be predicted from the meaning of the individual words.

Grammatically, there are certain restrictions that vary from one idiom to another regarding the grammatical functions. Al-Sulaimaan (2016:200) listed these restrictions as follows:

a. Idioms are not changeable regarding the plurality. If they have singular form and vice versa.

b. The tense of idioms is fixed, i.e. if the idiom is in present tense, it cannot be changed into plural.

c. They have no comparative and superlative forms.

d. It is not possible to change the voice form from active into passive and vice versa. So, idioms have fixed phrases which cannot be changed as well as fixed meaning.

\section{Idioms and Translation}

As for translation, idioms could be defined in terms of non-equivalence from one language into another. Idioms should not be translated literally. It is more appropriate to fine a rendering that can convey the same meaning and effect in the target language as in the source one.

Ghazala (2007: 128-130) classifies the translation of idioms from English into Arabic in terms of directness and indirectness:

\section{Direct idioms}

Translators might not face problems with direct idioms. They can find the equivalents in target language that have an appropriate meaning or similar to the one in the source language. For example,

A true friend does not stab in the back.

الصديق الحقيقي لا يطعن في الظهر.

\section{Indirect idioms}

This type of idioms might cause problems and mistakes in their translation because the translators cannot find equivalent in the target language. For example, 


\section{QALAAI ZANISTSCIENTIFIC JOURNAL \\ A Scientific Quarterly Refereed Journal Issued by Lebanese French University - Erbil, Kurdistan, Iraq \\ Vol. (6), No (4), Autumn 2021 \\ ISSN 2518-6566 (Online) - ISSN 2518-6558 (Print)}

He can walk on water.

يستطيع صنع المعجزات

\subsection{Types of Translation}

Newmark (1988:46) discusses the following types of translation: semantic communicative translation and adaptation. His classification is considered an important contribution to the studies of translation. They will be briefly explained as follows:

\subsubsection{Semantic Translation}

It focuses on the source language text, for this reason it can be said that it is semantically and syntactically- oriented. Besides, it is more literal and faithful; the translator should follow the source language text. It is described of being more complex, more detailed and more awkward.

\subsubsection{Communicative Translation}

It focuses on the target language text to help the reader comprehend it. This method is used to translate pragmatic texts, so the meaning will be rendered contextually. It also concentrates on the effectiveness of the message on the reader. Therefore, it is described as freer. It is also smoother, simpler and more direct.

\subsubsection{Adaptation}

It is considered as a free translation. It is important; in order to achieve a perfect translation, the translator should go beyond the words. The meaning of the words can be extracted according to the context. It is necessary to know that adaption is linked to culture. When there is something belongs to a specific culture and it is expressed differently in another culture, the translator has to change the SL expression or the text if it is not found in the TL.

In what follows, the types mentioned above are applied in translating the examples in data analysis. 


\section{QALAAI ZANISTSCIENTIFIC JOURNAL \\ A Scientific Quarterly Refereed Journal Issued by Lebanese French University - Erbil, Kurdistan, Iraq \\ Vol. (6), No (4), Autumn 2021 \\ ISSN 2518-6566 (Online) - ISSN 2518-6558 (Print)}

\section{Data Analysis}

The best way for comprehending idioms is to be used in context. Since the idioms are in widespread use, the English learners need to know how they are used and what they mean. The following idioms have been chosen form (English Idioms in Use) and translated into Arabic to show the similarities and differences between them.

\section{Idioms Expressing Happiness and Sadness.}

- SL: I am on the top of the world.

TL:

انا على قمة العالم. (Semantic Translation)

انا في قمة السعادة. (Communicative Translation)

انا فوق النخل. (Adaptation)

Table: (1) A

\begin{tabular}{|c|c|c|c|}
\hline \multirow{2}{*}{ SL } & \multicolumn{3}{|c|}{ TL } \\
\cline { 2 - 4 } & Semantic & Communicative & Adaptation \\
\hline $\begin{array}{c}\text { on the top of the } \\
\text { world }\end{array}$ & فوق العمة العبادة & & \\
\hline
\end{tabular}

- SL: Jack is down in the dumps, because he does not like his new job. TL:

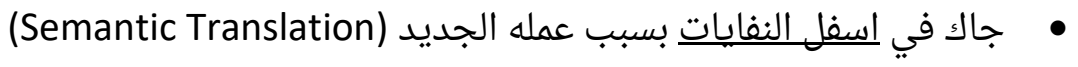

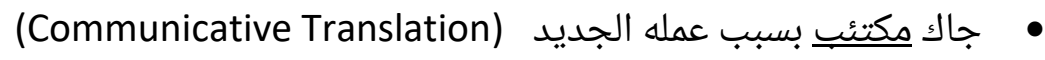

$$
\text { جاك وضعه زفت/ مترد. (Adaptation) }
$$

"down in the dumps" means that Jack is unhappy with his job. It is important to know that this expression is informal. It is clear that the second and the third renderings are the correct ones. The third rendering is used in the colloquial Arabic.

Table: (1) B

\begin{tabular}{|l|l|c|c|}
\hline \multirow{2}{*}{ SL } & \multicolumn{3}{|c|}{ TL } \\
\cline { 2 - 4 } & Semantic & Communicative & Adaptation \\
\hline
\end{tabular}




\section{QALAAI ZANISTSCIENTIFIC JOURNAL}

A Scientific Quarterly Refereed Journal Issued by Lebanese French University - Erbil, Kurdistan, Iraq

Vol. (6), No (4), Autumn 2021

ISSN 2518-6566 (Online) - ISSN 2518-6558 (Print)

\begin{tabular}{|c|c|c|}
\hline Down in the dumps & اسفل النفايات & مكتئب \\
\hline
\end{tabular}

\section{Idioms Expressing Knowledge}

SL: She knows the system inside out.

TL:

هي تعرف النظام داخل وخارج. (Semantic Translation)

هي تعرف كل صغيرة وكبيرة. (Communicative Translation)

The SL idiom means that she knows every detail about it. It is translated semantically and communicatively into Arabic, but the second translation is the correct one, simply, because it conveys the meaning that has the same effect.

Table: (2)

\begin{tabular}{|l|l|l|c|}
\hline \multirow{2}{*}{ SL } & \multicolumn{3}{|c|}{ TL } \\
\cline { 2 - 4 } & Semantic & Communicative & Adaptation \\
\hline $\begin{array}{l}\text { the system inside } \\
\text { out }\end{array}$ & النظام داخل وخارج وغيرة وكبيرة & \\
\hline
\end{tabular}

\section{Idioms Describing Critical Situation (Dilemma)}

SL: They have got me over the barrel.

TL:

(Semantic Translation). رموني فوق البرميل

تركوني في وضع صعب. (Communicative Translation)

تخلوا عني.(Adaptation)

The SL example means that they have put him in a situation where he has no choice over what he can do. It has three different renderings in the TL the second. The communicative translation was used in the second one and adaption in the third one. 


\section{QALAAI ZANISTSCIENTIFIC JOURNAL}

A Scientific Quarterly Refereed Journal Issued by Lebanese French University - Erbil, Kurdistan, Iraq

Vol. (6), No (4), Autumn 2021

ISSN 2518-6566 (Online) - ISSN 2518-6558 (Print)

Table: (3)

\begin{tabular}{|c|c|c|c|}
\hline \multirow{2}{*}{ SL } & \multicolumn{3}{|c|}{ TL } \\
\cline { 2 - 4 } & Semantic & Communicative & Adaptation \\
\hline over the barrel & وضع صعب & التخبل & وقيل \\
\hline
\end{tabular}

\section{Idioms for having Responsibility}

SL: Sally has had to carry the can.

TL:

كان على سالي حمل العلبة. (Semantic Translation)

كان على سالي تحمل المسؤولية. (Communicative Translation)

The example in the SL means that Sally has had to accept the blame or the responsibility alone, even though other people were responsible. It is translated semantically and communicatively. The second translation is the best one, because it has the same meaning of the SL.

Table: (4)

\begin{tabular}{|c|c|c|c|}
\hline \multirow{2}{*}{ SL } & \multicolumn{3}{|c|}{ TL } \\
\cline { 2 - 4 } & Semantic & Communicative & Adaptation \\
\hline to carry the can & حمل العلبة المسؤولية & تحمل \\
\hline
\end{tabular}

\section{Idioms Expressing Social Status}

$\mathrm{SL}$ : He is very nice, but his brother is very toffee-nosed.

TL:

• هو لطيف لكن اخاه حلو الانف جدا. (Semantic Translation)

• هو شخص لطيف جدا الا ان اخاه متعالٍ جدي.ً. (Communicative Translation)

هو شخص لطيف جدا الا ان اخاه متعجرف/ متكبر/ شايف نفسه شوفة/خشمه عالي.

Toffee-nosed in the SL text means that the person is of a high social class and looks down on people of lower class. This phrase has two different renderings in Arabic, 


\section{QALAAI ZANISTSCIENTIFIC JOURNAL}

A Scientific Quarterly Refereed Journal Issued by Lebanese French University - Erbil, Kurdistan, Iraq

Vol. (6), No (4), Autumn 2021

ISSN 2518-6566 (Online) - ISSN 2518-6558 (Print)

however the second one is the correct rendering because it conveys the same meaning of SL one.

Table: (5)

\begin{tabular}{|c|c|c|c|}
\hline \multirow[t]{2}{*}{ SL } & \multicolumn{3}{|c|}{ TL } \\
\hline & Semantic & Communicative & Adaptation \\
\hline toffee-nosed & حلو الانف جداً & متعالٍ جداً & متعجرف/متكبر/شايف \\
\hline
\end{tabular}

\section{Idioms Expressing Oneself}

SL: You must not be afraid to speak your mind; it is important that everyone hears your views.

TL:

يجب ان لاتخشى من الكلام عن مافي عقلك لانه من الضروي ان يسمع كل شخص ارائك

(Semantic Translation)

يحب عليك انتعير عن رايك من دون تحفظ. (Communicative Translation)

It is clear from the example in the SL text that the speaker asks the listener to state his opinion clearly and frankly by using "your mind" which translated twice into Arabic one is semantically and the other one communicatively. The communicative translation is the more appropriate in this example for the effectiveness that it conveys.

Table: (6)

\begin{tabular}{|c|c|c|c|}
\hline \multirow{2}{*}{ SL } & \multicolumn{3}{|c|}{ TL } \\
\cline { 2 - 4 } & Semantic & Communicative & Adaptation \\
\hline to speak your mind & تعبر عن رأيك دون تحفظ 203 & - \\
\hline
\end{tabular}

7. Idioms Expressing Colours

$\mathrm{SL}$ : The boss gave me the green light. 


\section{QALAAI ZANISTSCIENTIFIC JOURNAL \\ A Scientific Quarterly Refereed Journal Issued by Lebanese French University - Erbil, Kurdistan, Iraq \\ Vol. (6), No (4), Autumn 2021 \\ ISSN 2518-6566 (Online) - ISSN 2518-6558 (Print)}

TL:

$$
\text { • • }
$$

The "green light" in English means the permission given by someone for something to intiates. It is obvious that this idiom has an equivalent in the TL (Arabic) represented by "الضوء الاخضر" which is used to convey the same meaning in Arabic. It can be said that this example can be translated semantically and communicatively.

Table: (7)

\begin{tabular}{|c|c|c|c|}
\hline \multirow{2}{*}{ SL } & \multicolumn{3}{|c|}{ TL } \\
\cline { 2 - 4 } & Semantic & Communicative & Adaptation \\
\hline the green light & الضوء الاخضر الاخضر & \\
\hline
\end{tabular}

\section{Idioms Expressing Body Parts}

SL: Sam opened his heart to me.

TL:

فتح سام لي قلبه. (Semantic Translation)

فضفض لي سام عما في داخله. (Communicative Translation)

افصح لي سام عما في داخله. (Communicative Translation)

افصح لي سام عما في ذهنه. (Adaptation)

"opened his heart to me" is used in English to say that that someone shares his deepest feelings with someone else. This expression can be translated into Arabic by saying "افصح عما في ذهنه "or". It can be said that this idiomatic expression may be translated into Arabic by using semantic, communicative translation or even adaptation; all can convey the same meaning that this expression has in English.

Table: (8)

\begin{tabular}{|c|c|c|c|}
\hline \multirow[t]{2}{*}{ SL } & \multicolumn{3}{|c|}{ TL } \\
\hline & Semantic & Communicative & Adaptation \\
\hline open his heart & فتح لي قلبه & فضفض عمل في داخله & افصح عما في ذهنه \\
\hline
\end{tabular}




\section{QALAAI ZANISTSCIENTIFIC JOURNAL}

A Scientific Quarterly Refereed Journal Issued by Lebanese French University - Erbil, Kurdistan, Iraq

Vol. (6), No (4), Autumn 2021

ISSN 2518-6566 (Online) - ISSN 2518-6558 (Print)

\begin{tabular}{|l|l|l|}
\hline & & افصح عما في داخله
\end{tabular}

\section{Idioms Expressing Emphasis}

SL: (A) You can borrow my car tonight.

(B) Thanks a million!

TL:

(أ) بامكانك استعارة/اخذ سيارتي الليلة. (ب) مليون شكر (Semantic Translation)

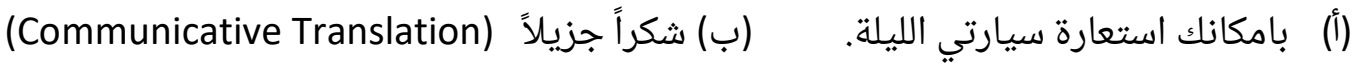

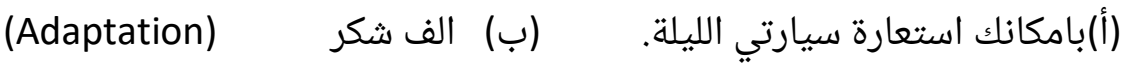
"thanks a million" is one of many expressions used by a person who would like to thank someone very much indeed. It was translated semantically, communicatively and adaptation was also used. The last two renderings are the correct ones and the third one is used in the colloquial Arabic.

Table: (9)

\begin{tabular}{|c|c|c|c|}
\hline \multirow{2}{*}{ SL } & \multicolumn{3}{|c|}{ TL } \\
\cline { 2 - 4 } & Semantic & Communicative & Adaptation \\
\hline Thanks a million & مليون شكرا جزيلا & & \\
\hline & & & \\
\hline
\end{tabular}

\section{Idioms Expressing Updateness}

SL: My computer is out of date.

TL:

ان حاسوبي قد مضى عليه الزمن. (Semantic Translation)

(Communicative Translation). ان حاسوبي قديي

حاسوبي عفى عليه الزمن.(Adaptation)

"out of date" in the SL text means that the computer is old and not useful anymore. It has been rendered into Arabic by giving three different translations. The first one 


\section{QALAAI ZANISTSCIENTIFIC JOURNAL}

A Scientific Quarterly Refereed Journal Issued by Lebanese French University - Erbil, Kurdistan, Iraq

Vol. (6), No (4), Autumn 2021

ISSN 2518-6566 (Online) - ISSN 2518-6558 (Print)

has a semantic meaning, while the econ one has been translated communicatively and adaptation was followed in the third one. The third rendering is the best one for the this idiom.

Table: (10)

\begin{tabular}{|c|c|c|c|}
\hline \multirow{2}{*}{ SL } & \multicolumn{3}{|c|}{ TL } \\
\cline { 2 - 4 } & Semantic & Communicative & Adaptation \\
\hline out of date & مضى عليه الزمن عليه الزمن & & \\
\hline
\end{tabular}

\section{Conclusions}

The current study came up with following conclusions:

1. The idiomatic expressions are culture-specific. They are used by native speakers. Due to the cultural divergences idioms might be difficult to be understood by English language learners.

2. Idioms are of two kinds as far meaning is concerned; a. transparent idioms which are not problematic because they are language- universal, and b. opaque idioms which are really idiomatic since they are language-specific.

3. Most idiomatic expressions were translated communicatively and in certain cases adaptation was used. These two types of translation result in effective rendering.

\section{References:}

Al-Sulaimaan, M.M. D. (2016): Semantics and Pragmatics, Erbil: Haval Press.

Chomsky, N. (1975): Reflections on Language, New York: Random House.

Hockett, C. F. (1958): A Course in Modern Linguistics, The Macmillan Company: New York. Ghazal, H. (2003): Translations as Problems and Solutions, Beirut: Dar wa Maktabat Al Hilal Newmark, P. (1988): A Textbook of Translation Studies, London: Prentice Hall.

O' Dell, F. and Michael McCarthy, (2017): English Idioms In Use, Cambridge: Cambridge University Press.

Ulman, S. (1962): Semantics: An Introduction to the Science of Meaning, Oxford: Balckwell. 


\section{QALAAI ZANISTSCIENTIFIC JOURNAL}

A Scientific Quarterly Refereed Journal Issued by Lebanese French University - Erbil, Kurdistan, Iraq

Vol. (6), No (4), Autumn 2021

ISSN 2518-6566 (Online) - ISSN 2518-6558 (Print)

\section{كرفتهكانى وهركَيّرانى دهستهوازهى زاراوهيى لهئينكليزييهوه بوّ عهرهبى}

يوخته:

دهستهوازمى زاراوهيى بهوه دهناسريّن كه ئهوانه كوّمهلَه وشهنه يان دهستهوازهنه يِيّكهوه بهكارديّن

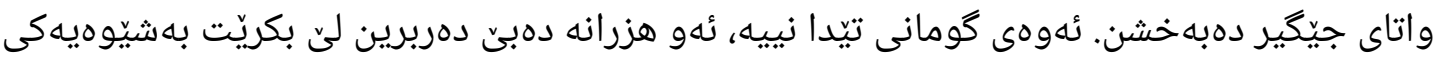

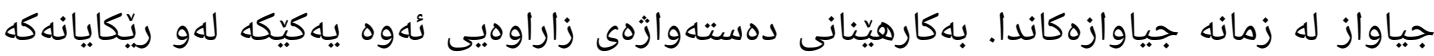

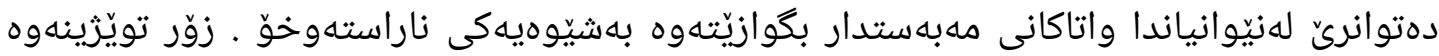

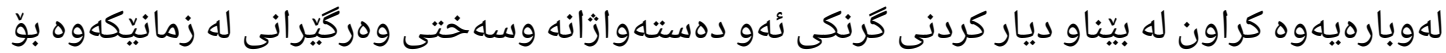

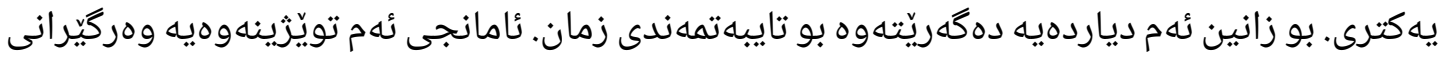

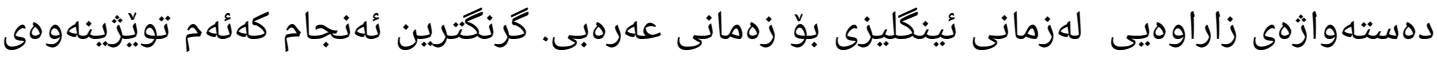

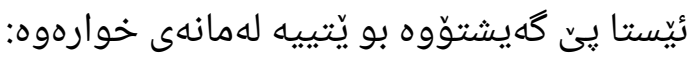

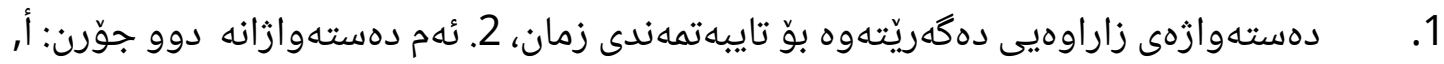

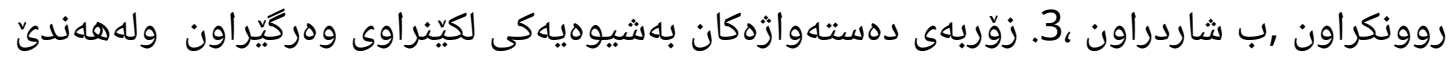

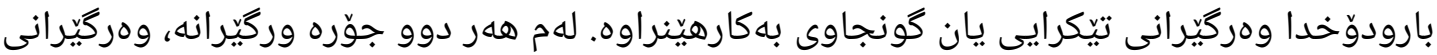
كارايى دروست بووه.

\section{مشكلات ترجمة التعابير الاصطلاحية من الانكليزية الى العربية}

المستخلص

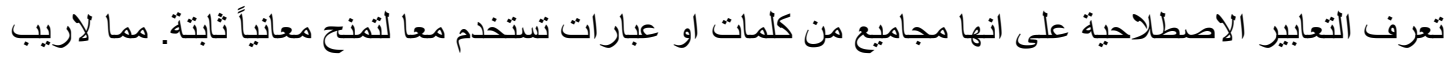

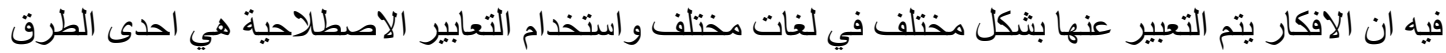

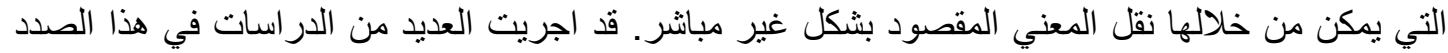

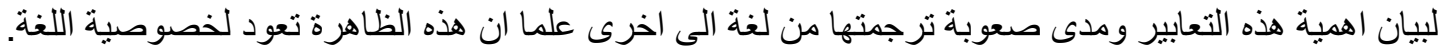

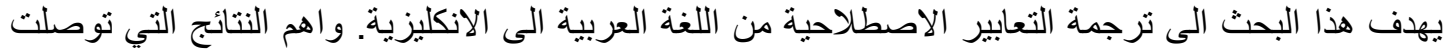

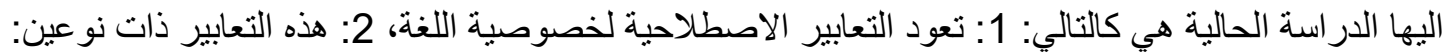

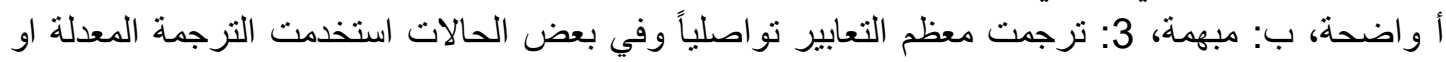
المكيفة. اذ نتج عن هاتين الطريقتين ترجمات فاعلة مدئ. 